\title{
THE SIGNIFICANCE OF PORPHYRINURIA IN LEAD POISONING ${ }^{1}$
}

\author{
By ROBERT KARK 2 AND ARNOLD P. MEIKLEJOHN 3 \\ (From the Thorndike Memorial Laboratory, Second and Fourth Medical Services (Harvard), \\ Boston City Hospital, and the Department of Medicine, Harvard Medical School, Boston)
}

(Received for publication September 24, 1941)

A pathologic increase in the amount of porphyrin excreted in the urine by patients with lead poisoning was first reported by Garrod (1) in 1892. Since then it has been generally assumed that this porphyrinuria is related in some way to the destruction of hemoglobin. Until recently there has been no means of testing the validity of this belief. Lately, however, the advance in knowledge concerning the chemistry of the porphyrins, and the development of methods for distinguishing one type from another, have provided a new approach towards an understanding of the underlying metabolic disorder responsible for the porphyrinuria of plumbism.

The isomeric identity of the Type III coproporphyrin found in the urine in lead poisoning with the Type III protoporphyrin of hemoglobin has been demonstrated by Grotepass (2) and by Watson (3). The porphyrin in the urine in lead poisoning thus fundamentally differs from the Type I isomer which is the predominant type excreted in several other conditions associated with porphyrinuria. These facts justify the assumption that the porphyrinuria in lead poisoning is a consequence of some alteration in the metabolism of hemoglobin itself. In theory, it might originate from an altered synthesis of hemoglobin just as probably as from hemoglobin destruction; but owing to the traditional belief that the anemia in lead poisoning is hemolytic in nature, only the latter possibility has received any general attention until recently. The hypothesis that the coproporphyrin excreted in lead poisoning is a product of hemoglobin destruction requires, however, an additional corollary. In pathologic conditions as-

\footnotetext{
1 The expenses of this investigation were defrayed in part by the J. K. Lilly gift to the Harvard Medical School.

2.Rockefeller Travelling Fellow; Research Fellow in Medicine, Harvard Medical School; Research Fellow, Thorndike Memorial Laboratory, Boston City Hospital.

8 Instructor and Francis Weld Peabody Fellow in Medicine, Harvard Medical School; Research Fellow, Thorndike Memorial Laboratory, Boston City Hospital.
}

sociated with excessive hemoglobin destruction, the breakdown products are eliminated in the bile in the normal manner without any large increase in the amount of Type III porphyrin excreted in the urine. Therefore, if the increased output of coproporphyrin in lead poisoning is conceived to be on the basis of increased destruction of hemoglobin, it is necessary to postulate that one effect of lead is to cause a partial interference in the pathway by which hemoglobin is normally broken down to bilirubin. Thus, it must be assumed that part of the destroyed blood pigment is diverted from the bile and appears in the urine with its original ring structure still intact.

In view of these considerations, it seemed of interest to study the mechanism of hemoglobin destruction in patients with lead poisoning. Evidence of some defect in this process would lend support to the hypothesis that the porphyrin appearing in the urine in this condition is derived from the breakdown of hemoglobin. On the other hand, failure to obtain such evidence would furnish additional support for the more recent theory that this porphyrinuria is a consequence of defective hemoglobin synthesis.

The experiments described in this paper were carried out on two patients suffering from lead poisoning with anemia and porphyrinuria. An attempt was made to trace the path of hemoglobin destruction in these patients by observing the effect of injected hemoglobin on the production of bilirubin and on the excretion of coproporphyrin and urobilinogen in the urine and feces.

\section{METHODS AND MATERIAL.}

During the period of investigation the patients were confined to bed and, in order to reduce the possibility of dietary porphyrins contributing to the estimated porphyrin excretion, partook of a meat, fish, and egg-free diet. All urine and feces were collected in dark glass containers and kept in an icebox with toluol as a preservative. In successive 24-hour specimens of urine the coproporphyrin was measured by a modification of the method of Brugsch and Keys (4) previously described by us (5). The fecal 
coproporphyrin excretion was measured on aliquots from successive 3-day accumulations of the stools by a modification of the same method which is described in detail below. The urobilinogen excreted in the urine and feces was estimated by Watson's (6) method. Plasma and urinary hemoglobin were estimated by Bing and Baker's (7) modification of Wu's method; and plasma bilirubin by Barron's (9) method. Hemoglobin solutions were prepared for intravenous injection by the method of Ottenberg and Fox (8).

\section{The estimation of ether-soluble porphyrin in the feces}

The 3-day collection of feces is weighed as collected and transferred to the beaker of an electric mixer. The large lumps are broken down with a glass stirring rod, and water is gradually stirred in to bring the volume to a given amount (usually $1000 \mathrm{ml}$.). The feces and water are thoroughly mixed into a paste by means of an electric stirrer and a measured volume, equivalent to 10 grams of the original weight of the stool, is taken out with a measuring cylinder and transferred to a mortar. The paste is then repeatedly ground up with 1 to $2 \mathrm{ml}$. glacial acetic acid and 20 to $40 \mathrm{ml}$. of ether. The acetic acid-ether extracts are decanted into a brown half-liter bottle and, finally, when no more color can be extracted from the stool by the acetic acid-ether mixture, the stool is also added to the contents of the bottle. The bottle is then shaken on a machine for 2 hours. The acetic acidether and feces mixture is filtered. The residue on the filter paper is mixed with more acetic acid, further ether is added and the filtration repeated. The two filtrates are then combined.

The total acetic acid-ether extract is washed six times with water in a separatory funnel, drained and extracted three times on the rotary machine with $10 \mathrm{ml}$. lots of 5 per cent $\mathrm{HCl}$ solution. A final extraction is made with $10 \mathrm{ml}$. of 10 per cent $\mathrm{HCl}$. The $\mathrm{HCl}$ extracts are combined and neutralized to Congo red by the addition of sodium acetate crystals. The neutral solution is repeatedly extracted with $10 \mathrm{ml}$. amounts of acetic acid and $100 \mathrm{ml}$. amounts of ether until there is no red fluorescence visible in the acetic acid-ether layer when examined by ultraviolet light.

The acetic acid-ether extracts are combined, washed six times with water, drained and reextracted with 5 per cent and 10 per cent $\mathrm{HCl}$ as previously. This whole procedure is repeated three times but during the final $\mathrm{HCl}$ extraction only 5 per cent $\mathrm{HCl}$ is used.

The combined 5 per cent $\mathrm{HCl}$ extracts are now shaken repeatedly with $5 \mathrm{ml}$. chloroform until the chloroform layer shows no red fluorescence when held in front of the ultra-violet lamp. The acid fraction is now diluted to 0.05 per cent $\mathrm{HCl}$ by the addition of distilled water and again repeatedly extracted with $5 \mathrm{ml}$. amounts of chloroform. These steps are introduced to remove any protoporphyrin which may be present. The 0.05 per cent $\mathrm{HCl}$ extract is then made neutral to Congo red by the addition of sodium acetate crystals and the neutral solution repeatedly extracted with acetic acid and ether as previously. The combined acetic acid-ether extracts are washed, drained and reextracted with $5 \mathrm{ml}$. amounts of 5 per cent $\mathrm{HCl}$. The combined $\mathrm{HCl}$ extracts are made up to a suitable volume and read in the same manner as the final $\mathrm{HCl}$ extracts obtained from the urine. The per diem excretion of porphyrin in the feces can be calculated by using the following equation:

\begin{tabular}{|c|c|c|}
\hline $\begin{array}{l}\text { Total weight of } 3 \text {-day } \\
\text { collection of feces }\end{array}$ & $\begin{array}{l}\text { Final volume of } \\
\mathrm{HCl} \text { extract }\end{array}$ & $\begin{array}{l}\text { The reading in } \\
\text { micrograms }\end{array}$ \\
\hline 10 & $\begin{array}{l}\text { Volume of } \mathrm{HCl} \\
\text { extract used for } \\
\text { reading against } \\
\text { standard }\end{array}$ & 3 \\
\hline
\end{tabular}

By this method the excretion of porphyrin in normal individuals varied from 80 to 280 micrograms per diem.

The two patients selected for study each possessed the characteristic features of lead poisoning.

Case 1. Case 1 was a 24-year-old white male who had been employed in polishing soldered metal surfaces. He was admitted to the hospital following an attack of colic and complained of weakness, nervousness and constipation. His gums showed a well-marked lead line, but there was no evidence of neuritis. His hemoglobin was 54 per cent (Sahli), red blood cells 2.73 million per cubic millimeter, hematocrit 25 per cent, reticulocytes 9.6 per cent with 1 or 2 stippled cells visible in each high powered field. The blood lead was $0.007 \mathrm{mgm}$. per 10 grams of blood (normal $0.002 \mathrm{mgm}$.).4

During his stay in the hospital, the urine was consistently normal in color, yet contained about 1000 micrograms of coproporphyrin in each 24-hour collection (Figure 1). The normal urinary excretion of coproporphyrin, as measured by the method employed, usually ranges between 20 and 40 micrograms, and rarely exceeds 96 micrograms in 24 hours. The daily fecal coproporphyrin excretion of Case 1 averaged about 200 micrograms. The urine never contained more than a trace of urobilinogen, and the fecal excretion of urobilinogen was always within normal limits.

It is interesting to note that the urinary excretion of coproporphyrin was unaffected by the administration of $500 \mathrm{mgm}$. of nicotinic acid or of 5 U.S.P. units of liver extract daily for 12 days (Figure 1). This therapy was administered in view of a published report (10) which claims that nicotinic acid reduces the porphyrinuria in lead poisoning.

4 The blood lead determination was very kindly performed by Dr. A. J. Plummer of the Evans Memorial Hospital. 


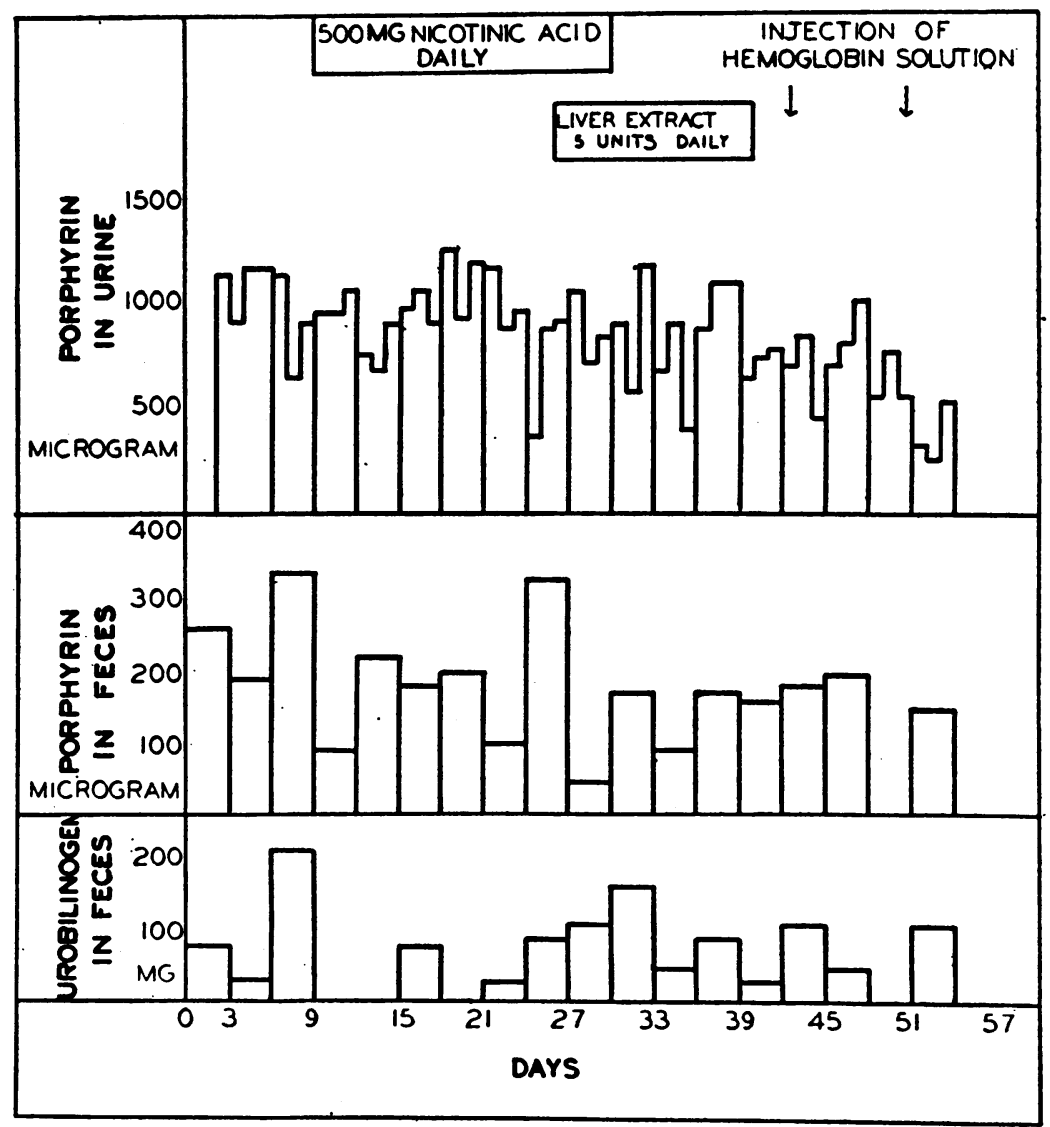

Fig. 1. Case 1. Excretion of Coproporphyrin in Urine and Feces, and Fecal Excretion of Urobilinogen Before and After Two Injections of About 7.5 and 19 Grams of Hemoglobin, Respectively

Case 2. Case 2 was a 40-year-old colored male lead smelter. He had been suffering from colic prior to admission and was constipated, nervous and "shaky." A definite lead line was present in the gums. No evidence of neuritis was noted. The hemoglobin was 60 per cent (Sahli), red blood cells 3.9 million per cubic millimeter. hematocrit 38 per cent, reticulocytes 6.7 per cent, stippled cells 1.8 per cent.

The urine was normal in color ${ }^{5}$ throughout his stay in the hospital but contained an average of 1200 micrograms of coproporphyrin in each 24-hour collection (Figure 2). The urinary excretion of urobilinogen varied from a trace to $4 \mathrm{mgm}$. a day. The amount of copro-

5 We wish to emphasize that in both the cases reported here the urine was entirely normal in appearance despite its abnormal content of porphyrin. It is evident that the port wine coloration, traditionally associated with porphyrinuria, is not found in lead poisoning owing to the absence of other associated pigments which are usually present where the urine contains excessive amounts of porphyrin. This question will be discussed more fully in a later communication. porphyrin in the feces was at first somewhat increased, averaging 450 micrograms a day for the first 9 days, but later fell to within normal limits. The excretion of urobilinogen in the feces was always within the limits of normal.

\section{RESULTS}

After a suitable control period in each case, solutions of hemoglobin were injected intravenously during a period of 30 minutes.

Case 1. In the first test, about 7.5 grams of hemoglobin derived from $50 \mathrm{ml}$. of normal blood were injected. This amount of hemoglobin, if totally destroyed, would yield theoretically about $250 \mathrm{mgm}$. of protoporphyrin. Following the injection, hemoglobin was detectable in the plasma and reached a peak of $55 \mathrm{mgm}$. per cent after one hour. The plasma bilirubin rose from a control level of 0.38 to a peak of 0.70 per cent in 4 hours. There was, therefore, a maximum increase of 0.32 


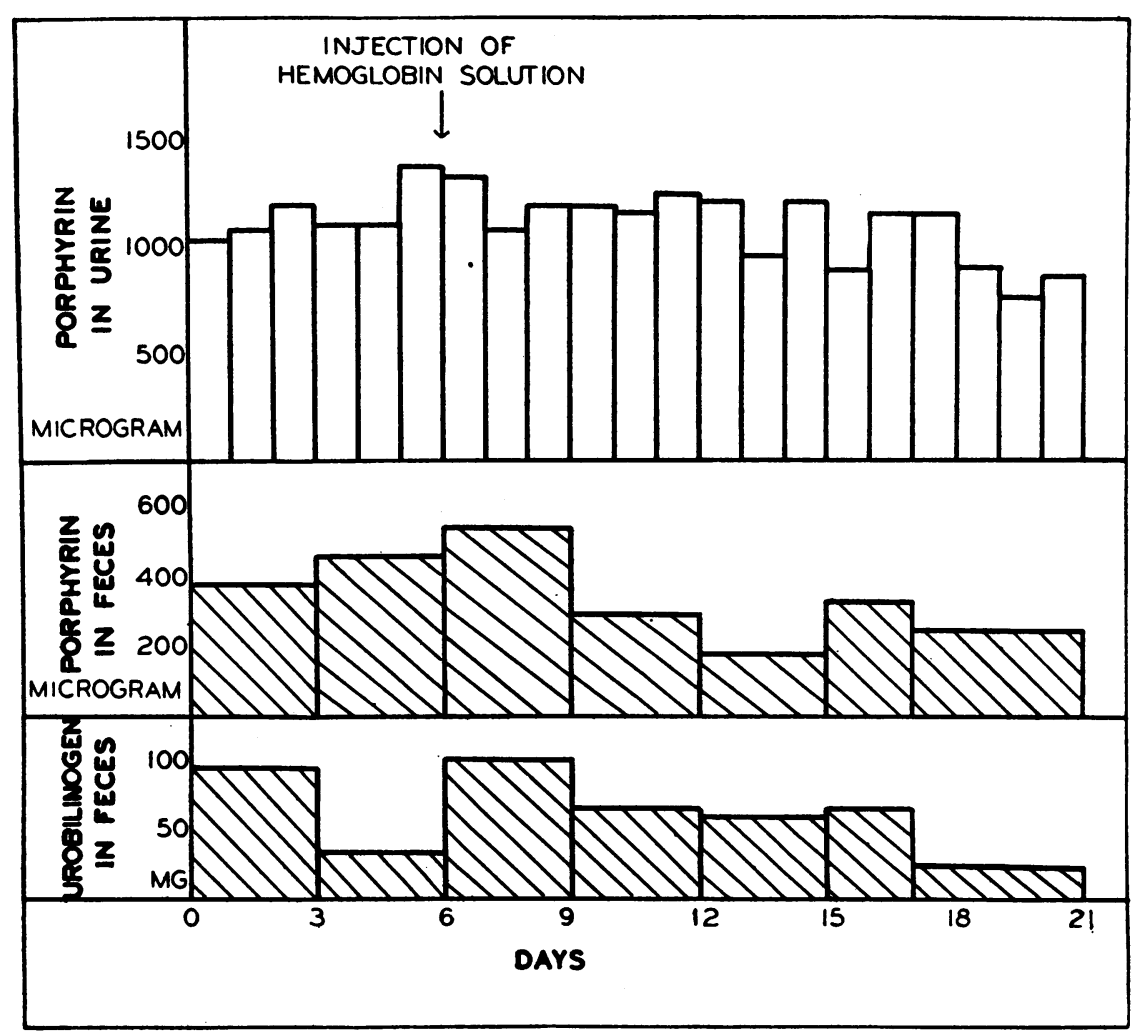

Fig. 2. Case 2. Excretion of Coproporphyrin in Urine and Feces, and Fecal Excretion of Urobilinogen Before and After an InJection of About 7.9 Grams of Hemoglobin.

mgm. of bilirubin per $100 \mathrm{ml}$. of plasma. Assuming the blood volume to have been approximately 5 liters, with the observed cell volume 25 per cent, about $12 \mathrm{mgm}$. of bilirubin derived from the injected hemoglobin must have been present in the circulating blood stream during the height of its production. It is fair to assume, therefore, that at least this amount of the $250 \mathrm{mgm}$. of protoporphyrin present in the injected hemoglobin was converted to bilirubin; yet none appeared as additional coproporphyrin in the urine. The urinary excretion of coproporphyrin was not increased even by 100 micrograms, an amount that would certainly have been detected by the method of estimation employed.

The fecal excretion of urobilinogen and coproporphyrin remained unchanged during the test (Figure 1) as did the urinary excretion of urobilinogen.

The second test on Case 1 was even more definitive. About 19 grams of hemoglobin derived from $125 \mathrm{ml}$. of normal blood and equivalent to $630 \mathrm{mgm}$. of protoporphyrin were injected intravenously. The maximum increase in plasma bilirubin following the injection was $2.8 \mathrm{mgm}$. per $100 \mathrm{ml}$. of plasma (Figure 3), from which the calculated maximum quantity of circulating bilirubin derived from the injected hemoglobin was about $100 \mathrm{mgm}$. However, as will be seen from Figures 1 and 3, the urinary excretion of coproporphyrin remained at a level of approximately 500 micrograms per 24 hours.

It is of interest that, in this test, the injection was followed by the excretion of $0.47 \mathrm{mgm}$. of hemoglobin in the urine, and in the 24 hours following the injection $7 \mathrm{mgm}$. of urobilinogen appeared in the urine.

As a control to these experiments, the levels of plasma bilirubin and urinary coproporphyrin excretion were measured over a previous 24-hour period. As may be seen in Figure 4, their levels did not fluctuate markedly. 


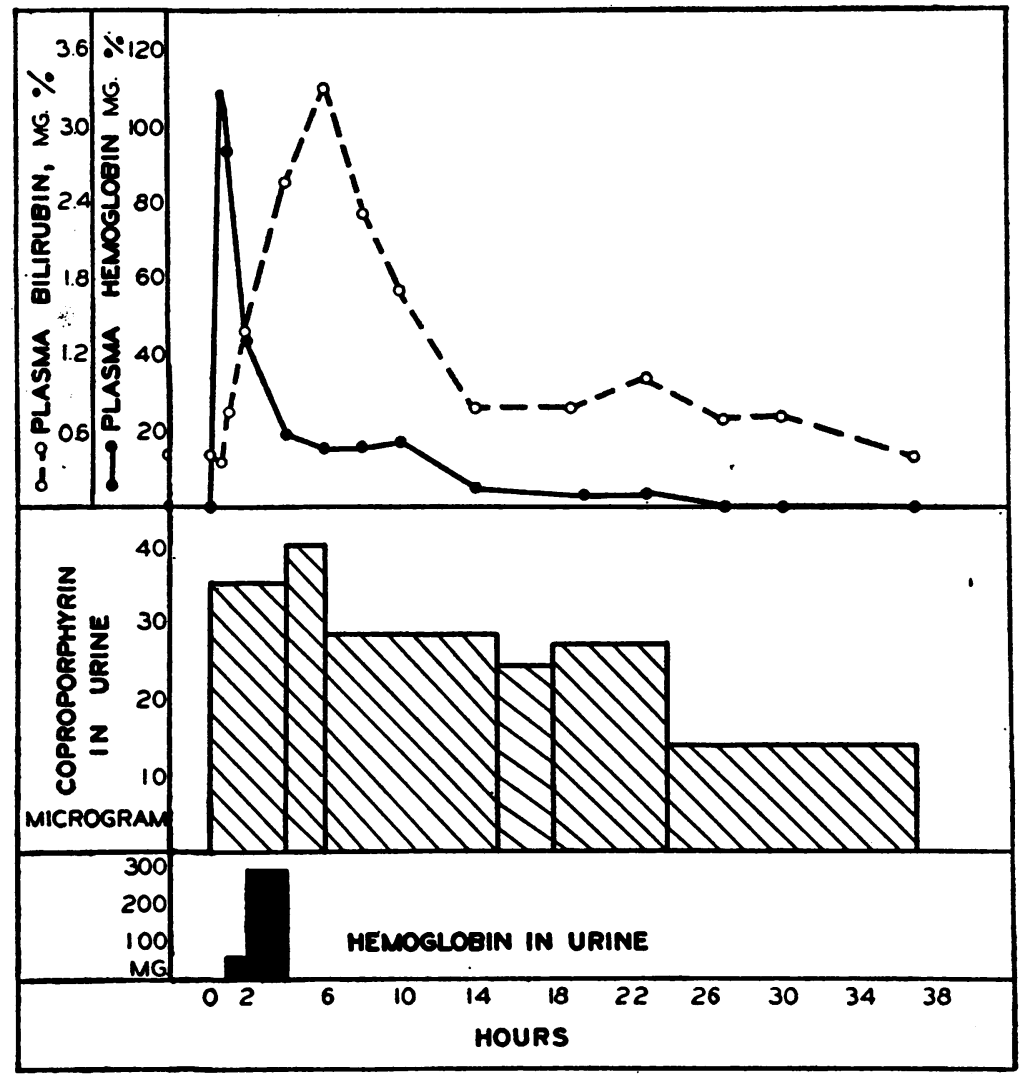

Fig. 3. Case 1. Plasma Bilirubin and Hemoglobin and Urinary Coproporphyrin and Hemoglobin Following the Intravenous Administration of About 19 Grams of Hemoglobin

Case 2. About 7.9 grams of hemoglobin derived from $100 \mathrm{ml}$. of the patient's own blood were injected. The amount of protoporphyrin which would be liberated if all this hemoglobin were broken down is about $260 \mathrm{mgm}$. Following the injection, the plasma bilirubin showed a maximum increase of $1.1 \mathrm{mgm}$. per cent (Figure 5). The red blood cell volume was 38 per cent and, assuming again that the blood volume was approximately 5 liters, $33 \mathrm{mgm}$. of bilirubin derived from the injected hemoglobin may be assumed to have been circulating in the blood stream at this time. The urinary excretion of coproporphyrin during the test is recorded in Figures 2 and 5 . It will be seen that no variations, even of the order of 100 micrograms, were observable in the 24-hour amount excreted.

There was no significant change in the fecal excretion of urobilinogen or coproporphyrin (Figure 4 ), though $0.8 \mathrm{mgm}$. of hemoglobin appeared in the urine shortly after the injection and $14 \mathrm{mgm}$. of urobilinogen was excreted in the urine during the succeeding 24 hours.

\section{DISCUSSION}

In both these patients the introduction of free hemoglobin into the blood stream was followed by a rapid rise in plasma bilirubin. This rise in bilirubin resembles very closely both in degree and time of onset the bilirubinemia observed by Gilligan et al. (11) in normal subjects under the same conditions. It is evident, therefore, that these two patients were able to convert hemoglobin to bilirubin without evidence of impairment of this process. Nevertheless, the transient increase in hemoglobin destruction produced by this experimental means resulted in no appreciable alteration in the amount of coproporphyrin excreted in the urine or feces, although the amount of hemoglobin injected was presumably sufficient to have pro- 


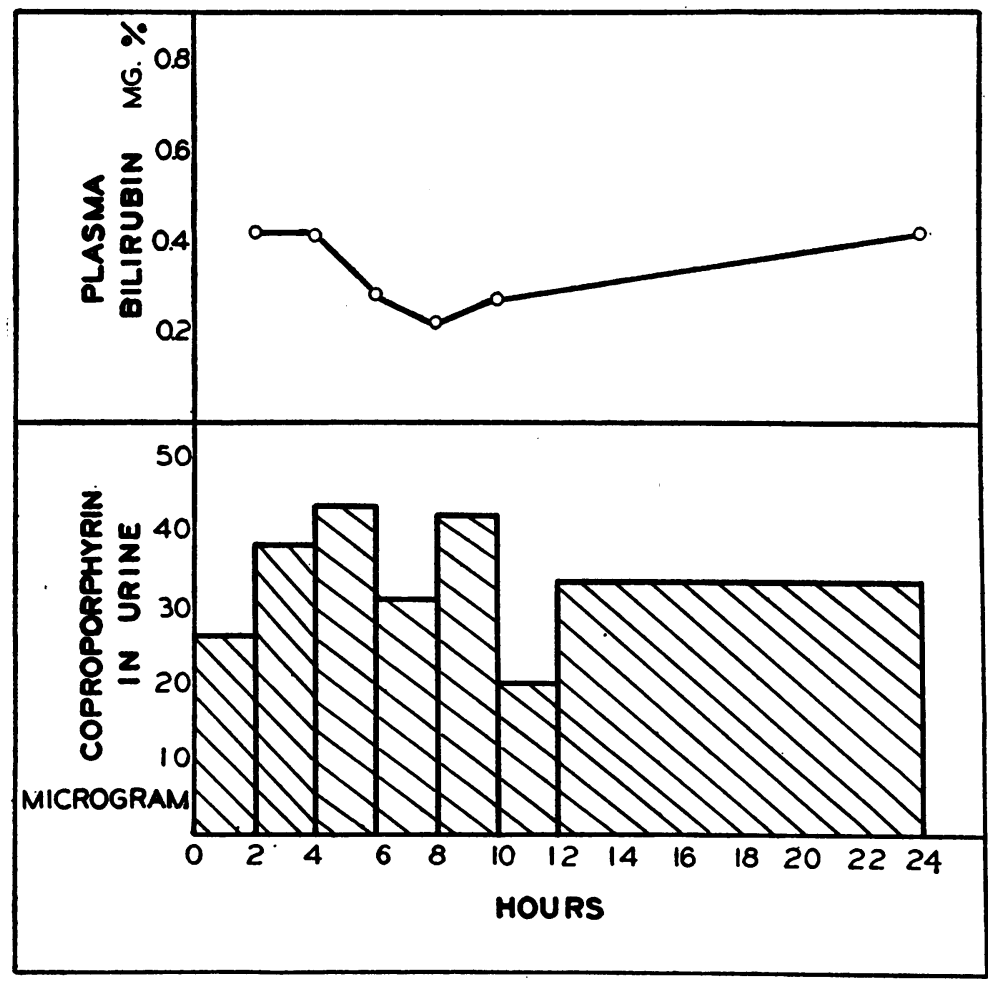

Fig. 4. Case 1. Plasma Bilirubin and Urinary Coproporphyrin During a 24-Hour Control Period

duced a definite rise in porphyrin excretion if any significant part of it had been eliminated in this form. These results suggest that there is no obvious defect in the mechanism of hemoglobin destruction in lead poisoning, and consequently that the porphyrinuria characteristic of this condition cannot be explained on the basis of such a defect occurring as a result of increased destruction of red blood cells.

A possible objection to this conclusion is the fact that these experiments did not succeed in demonstrating the ultimate fate of the injected hemoglobin. Though it was not excreted as porphyrin, it did not appear as an increase in fecal urobilinogen as might have been expected. However, it seems certain that at least some part of the hemoglobin was broken down, as judged by the consistent appearance of bilirubin in the plasma after each injection of hemoglobin, and the transient increase in urobilinogen in the urine in two instances. If a defect in hemoglobin breakdown was responsible for the increased porphyrin excretion before the injection of hemoglobin, one would have expected that at least a few additional milligrams of porphyrin would have appeared in the urine or feces as a result of the hemoglobin injections. However, no detectable alteration in porphyrin excretion was observed. The lack of increase in the fecal excretion of urobilinogen following the injection of hemoglobin was probably due to the conservation of bilirubin within the body. A similar discrepancy between the amount of hemoglobin destroyed and the excretion of its waste products in the bile has been noted by other authors (12).

It is logical to conclude that in plumbism the porphyrin excreted in the urine is not derived from any abnormal destruction of red blood cells, but is more probably a result of defective synthesis of hemoglobin. This conclusion is in agreement with the views recently expressed by Watson (13) and by Rimington (14). Watson states "It seems more likely that the formation of coproporphyrin III is related to a disturbance in the formation of hemoglobin rather than to its destruction." Rimington believes that the abnormal excretion of 


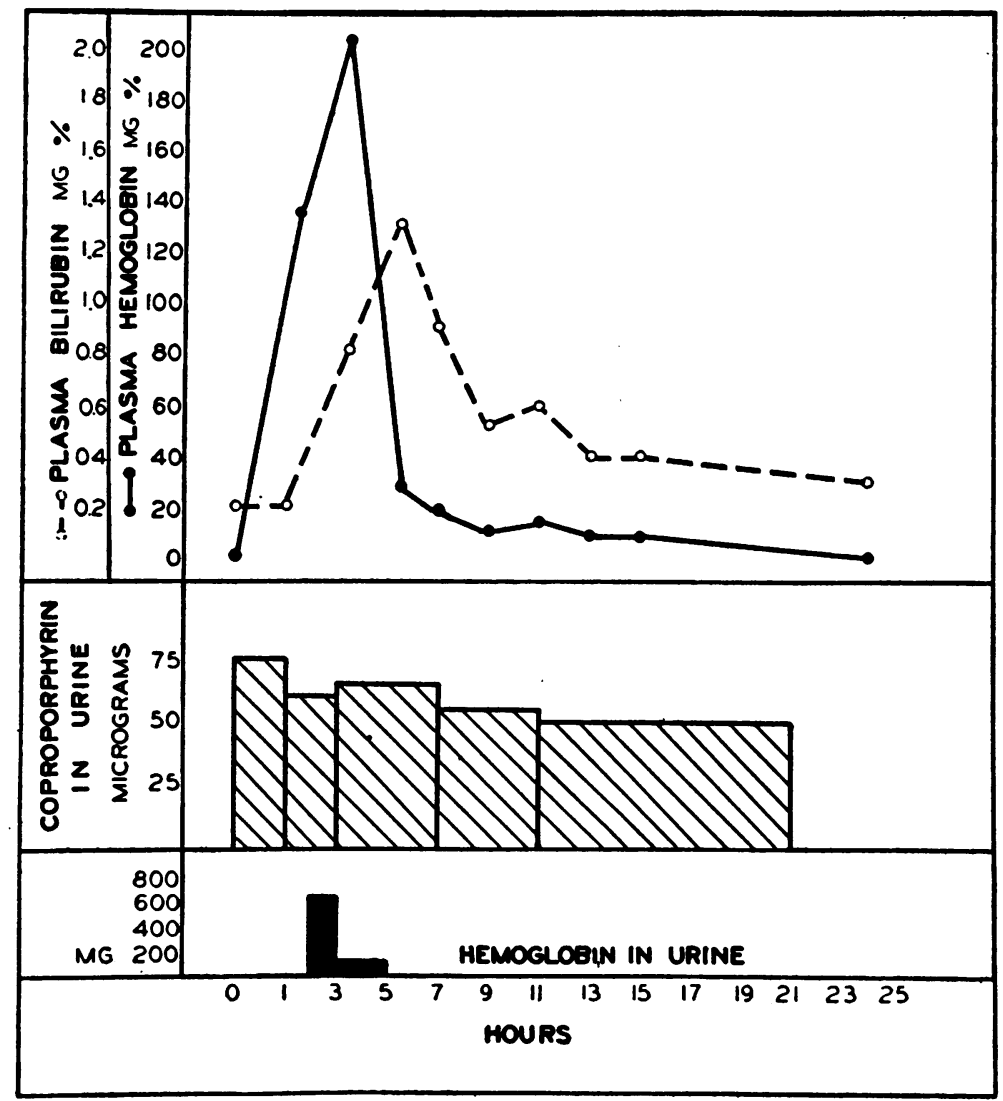

Fig. 5. Case 2. Plasma Bilirubin and Urinary Excretion of CoPROPORPHYRIN AND HeMoglobin Following the INTRAVENous Administration of About 7.9 Grams of Hemoglobin

coproporphyrin III results from partial block by toxic substances of the entrance of iron into the porphyrin ring and consequent defective synthesis of hemoglobin.

In view of this evidence it seems pertinent to reconsider the traditional belief that the anemia of lead poisoning is hemolytic in nature, and to inquire whether there is a possibility that defective hemoglobin synthesis may play a part in its production. The traditional hypothesis is supported by the following evidence. Aub, Reznikoff and Smith (15) clearly showed that if lead salts are added to normal blood the red cells shrink and seem to become more brittle, with resulting "fractionation" and escape of hemoglobin. Key (16) has produced a marked anemia in rabbits following the administration of lead salts, resulting in the loss of over one million red blood cells per cubic millimeter in 24 hours. Furthermore, the anemia of lead poisoning in man is accompanied by an apparent reticulocytosis comparable to the reticulocytosis occurring in hemolytic jaundice; it is possible, however, that this reticulocytosis may be of a "spurious" type such as occurs in cases of pernicious anemia treated with arsenic.

Against the hemolytic hypothesis it may be said that, although Aub and his collaborators showed that hemolysis may be caused by the addition of lead salts to blood in vitro, the amount of lead employed to produce this effect was very much more than is usually present in the blood in chronic lead poisoning. Thus, although their results may well explain the acute anemia produced in rabbits by Key, it is doubtful whether they furnish an explanation of the anemia in chronic lead poisoning.

As Watson (13) has pointed out, the anemia in human lead poisoning is usually associated with a color index below 1.0 , and by a reduced mean corpuscular hemoglobin concentration. This sug- 
gests a disturbance or retardation in the formation of hemoglobin. Moreover, as he (17) has shown, the excretion of urobilinogen in the feces is not increased as in other hemolytic conditions. This observation is confirmed by the results reported in the present communication. It must be concluded that, while the anemia produced by acute lead poisoning in rabbits is apparently hemolytic in nature, the evidence is against the view that the anemia commonly observed in chronic human lead poisoning can be explained on the same basis.

It is pertinent now to consider the possible origin of the coproporphyrin found in the urine in lead poisoning. Watson and Clarke (18) have lately shown that reticulocytes contain a considerable amount of protoporphyrin, and have suggested that this protoporphyrin is the material responsible for the reticulum in these cells. It is tempting to suggest that the characteristic appearance of the stippled cells found in the blood in lead poisoning is also due to a porphyrin, though of sufficiently different composition to modify its morphologic appearance. As pointed out above, there is evidence that the synthesis of hemoglobin is impaired in lead poisoning. The appearance of stippling in the red cells may therefore be an expression of an arrest in the maturation of hemoglobin and consequent accumulation of porphyrin products within the cells. It seems likely that, when the stippled cells are ultimately destroyed, this material would be liberated and, being an abnormal metabolite, might be excreted in an abnormal manner. This, therefore, might well account for at least some part of the larger amount of coproporphyrin III appearing in the urine. In support of this view, the observations of Thomas (19) may be mentioned. $\mathrm{He}$ has pointed out that, whereas hemoglobin injected into animals is excreted as bile pigments, injected hematin is recovered as porphyrin in the urine.

Whatever the ultimate explanation of porphyrinuria in lead poisoning, we believe that it is at least very intimately related to the same metabolic disturbance that gives rise to the stippling in the red blood corpuscles. This belief is borne out by some unpublished observations in which we found that, in a group of fourteen lead workers with porphyrinuria, the majority also showed the presence of stippled cells in the blood.

\section{SUMMARY ANB CONCLUSIONS}

Solutions of hemoglobin were injected into two subjects with lead poisoning, anemia and porphyrinuria. The injection was followed by a rise in plasma bilirubin resembling closely both in degree and time of onset the bilirubinemia which has been observed (11) in normal subjects under comparable conditions. It was also accompanied by transient increase in urinary urobilinogen excretion. The injection resulted in no detectable increase in the excretion of coproporphyrin either in the urine or feces.

These results failed to demonstrate any interruption in the path by which hemoglobin is destroyed in the body. It is, therefore, concluded that the porphyrinuria occurring in lead poisoning cannot be explained on this basis.

The relation of these findings to the problem of the causation of anemia in lead poisoning is discussed. It is concluded that they lend support to the view that this anemia is dyshematopoietic rather than hemolytic in nature.

We wish to express our grateful thanks to Miss Constance Brooks who performed the bilirubin and hemoglobin estimations, and to Frank P. Cohen, M.S., for his valuable assistance in carrying out quantitative determinations of porphyrin and urobilinogen. We also wish to thank Dr. Dorothy Rourke Gilligan for her advice on the procedure for injecting hemoglobin.

\section{BIBLIOGRAPHY}

1. Garrod, A. E., The occurrence and detection of hematoporphyrin in the urine. J. Physiol., 1892, 13, 598.

2. Grotepass, W., Zur Kenntnis des in Harn auftretenden Porphyrins bei Bleivergiftung. Ztschr. $f$. physiol. Chem., 1932, 205, 193.

3. Watson, C. J., Concerning the naturally occurring porphyrins. IV. The urinary porphyrins in lead poisoning as contrasted with that associated normally and in other diseases. J. Clin. Invest., 1936, $15,327$.

4. Brugsch, J. T., and Keys, A., Quantitative separation and estimation of various porphyrins in biological materials. Proc. Soc. Exp. Biol. and Med., 1938, 38, 557.

5. Kark, R., and Meiklejohn, A. P., Pellagra and porphyrinuria. Am. J. M. Sc., 1931, 201, 380.

6. Watson, C. J., Studies of urobilinogen. I. An improved method for the quantitative estimation of urobilinogen in urine and feces. Am. J. Clin. Path., 1936, 5, 458. 
7. Bing, F. C., and Baker, R. W., The determination of hemoglobin in minute amounts of blood by Wu's method. J. Biol. Chem., 1931, 92, 589.

8. Ottenberg, R., and Fox, C. L., The rate of removal of hemoglobin from the circulation and its renal threshold in human beings. Am. J. Physiol., 1938, 123, 516.

9. Barron, E. S. G., Bilirubinemia. Medicine, 1931, 10, 77.

10. Gross, E. S., Sasaki, Y., and Spies, T. D., Effect of nicotinic acid on increased porphyrinuria occurring in seven painters. Proc. Soc. Exp. Biol. and Med., 1938, 38, 289.

11. Gilligan, D. R., Altschule, M. D., and Katevsby, E. M., Studies of hemoglobinemia and hemoglobinuria produced in man by intravenous injection of hemoglobin solution. J. Clin. Invest., 1941, 20, 177.

12. Watson, C. J., in Downey's Handbook of Hematology. Paul B. Hoeber, Inc., New York, 1938, vol. IV, p. 2490.
13. Watson, C. J., in a symposium on the blood and blood forming organs. University of Wisconsin Press, Madison, 1939, p. 25.

14. Rimington, C., Porphyrinuria following sulphanilamide: Sulphanilamide dermatitis. Lancet, 1938, 1, 770.

15. Aub, J. C., Reznikoff, P., and Smith, D. E., Lead studies. III. The effect of lead on red blood cells. Part I. Changes in hemolysis. J. Exper. Med., 1924, 40, 151.

16. Key, J. A., Lead studies. IV. Blood changes in lead poisoning in rabbits, with especial reference to stippled cells. Am. J. Physiol., 1924, 70, 86.

17. Watson, C. J., Concerning the naturally occurring porphyrins. V. Porphyrins of the feces. J. Clin. Invest., 1937, 16, 383.

18. Watson, C. J., and Clarke, W., The occurrence of protoporphyrin in the reticulocytes. Proc. Soc. Exp. Biol. and Med., 1937, 36, 65.

19. Thomas, J., Contribution à l'étude des porphyrines en biologie et en pathologie. Duclume. Lonx-leSaunier, 1938, p. 73, 121. 